\title{
EGY IGAZI „HUNGARIKUM”: A HAZAI BANKI KÜLÖNADÓK SZABÁLYOZÁSÁNAK RÖGÖS ÚTJA ?*
}

\author{
Horváth Bettina ${ }^{l}$
}

Mostanáig tizenhét európai uniós országban vezettek be valamilyen banki különadót. Ezek között három fö típust különböztethetünk meg: a tranzakciós adót, bizonyos mérlegtételek alapján kivetett adót, és a nyereség alapján kivetett közterheket. Magyarországon háromféle banki különadó került bevezetésre az utóbbi egy évtizedben: a hitelintézeti járadék, a pénzügyi szervezetek különadója, amit a 2009-es mérlegföösszeg alapján vetettek ki, és amelynek mértéke többszöröse az Európában ismert átlagnak, valamint a tranzakciós illeték, amely a legnagyobb közfelháborodást keltette a lakosság körében. Meglátásom szerint ezek a bankszektort sújtó extra terhek $a z$ egész gazdaság fenntartható növekedését korlátozzák. Úgy vélem, ezeknek a különadóknak a regulációja sürgető reformokat kíván. Az új fejleményekre reflektálva ugyanakkor szeretnék rámutatni arra, hogy nem volna teljesen lehetetlen próbálkozás fenntarthatóvá tenni a banki különadók rendszerét a hazai adóstruktúrában. ${ }^{2}$

Érdemes még az elején tisztázni, hogy tulajdonképpen mit is értünk azalatt, hogy különadók és mégis mi lehet a létjogosultságuk a 21. századi adórendszerekben. Talán nem árulok el nagy titkot vele, de a különadók kifejezés alatt azokat a fizetési kötelezettségeket értjük, amelyek kizárólag bizonyos szektorokat, iparágakat vagy tevékenységeket terhelnek. Könnyen találkozhatunk ezeknek az adóknak úgynevezett válságadóként való definiálásával is, hiszen hazánkban legtöbbjük megjelenését valóban a 2008-as világválság indukálta. S hogy mire is jók? A különadók egyik legnagyobb erényeként a rugalmasságukat, formálhatóságukat lehetne említeni a hagyományos adónemekkel szemben. Gyorsan bevezethetök és pont emiatt viszonylag rövid idő alatt képesek különböző krízishelyzetek orvoslására a gazdaságban. Na de akkor miért is övezte és övezi jelenleg is annyi kritika ezeket a különadókat hazánkban?

Azok a bizonyos banki különadók...

A kérdés megválaszolásához térjünk is rá azokra a banki különadókra, amelyeket ideiglenes jellegünek szántak, de mára állandó közterhekké alakultak. A banki különadó bevezetésének a gondolata hazánkban elöször 2004-ben ütötte fel a fejét. Most több mint egy évtizeddel később járunk, s bár annak ellenére, hogy ezeket a különadókat tényleg csak átmeneti jellegünek szánták a magyar adóztatási rendszerben, három, a bankokat terhelö különadó jelenleg is megtalálható: a hitelintézeti járadék, a pénzügyi szervezetek különadója és hitelintézeti különadó, valamint a pénzügyi tranzakciós illeték. A bankszektor ily módon történő megsarcolásának számos indoka volt, a legkézenfekvőbb ezek közül az, hogy a bankmentések, tőkefeltöltések költségeit magukkal a bankokkal fizettessék meg. Mindemellett számos nem titkolt cél között

\footnotetext{
${ }^{*}$ DOI 10.21867/KjK/2017.1.3.

${ }^{1}$ Horváth Bettina, joghallgató, DE-ÁJK

2 A tanulmány egy korábbi változata az Ars Boni weboldalán jelent meg. Elérhető: http://arsboni.hu/kicsit-magas-kicsit-extrem-de-legalabb-mienk/
} 
szerepelt a felduzzadt államadósság redukálása, a költségvetési egyenleg javítása, tehát az államkassza helyrebillentése. Ugyanakkor nem utolsó sorban a nemzetközi trendeknek a magyar adóztatási struktúrára gyakorolt hatását is meg kell említenünk, ugyanis több EU tagállam vezetett be bankadót ez időben. Magyarországon az alapkoncepció tulajdonképpen az volt, hogy a bankszektor megadóztatása nem lehetetleníti el a müködését, de ezen a ponton figyelmen kívül hagytak egy igen fontos kérdést, vagyis azt, hogy tulajdonképpen ki lesz a végső megfizetője ennek az adótehernek? A bankok ugyanis ezeket az adóterheket vagy beépítik a szolgáltatásaik áraiba, tehát közvetett módon mi, a fogyasztók fizetjük meg, vagy vállalják a jövedelemtermelö képességük csökkenését ezzel a többletteherrel.

A banki különadók esetében tehát hangsúlyozom, hogy nem egy új keletü intézményről beszélünk az öreg kontinensen, de álláspontom szerint ez a magyar megvalósítás hagy annyi kívánnivalót maga után, hogy megéri górcső alá vennünk azt, hogy miért pont így, ilyen mértékben és módon került sor a bevezetésükre? Hogyan lehetett volna ezt jobban csinálni? Hogyan változott, avagy nem változott a magyarok bankolási szokása a hatásukra? Ezekre a kérdésekre keresem a választ a továbbiakban és az új fejleményekre tekintettel szeretnék rámutatni arra, hogy nem volna teljesen lehetetlen próbálkozás fenntarthatóvá tenni a banki különadók rendszerét a hazai adóstruktúrában.

Hitelintézeti járadék

Ahhoz, hogy jól megértsük, miért is társul annyi negatív felhang a magyar banki különadókhoz, fókuszáljunk az egyes adófajtákra külön-külön és nézzük miben állnak azok negatívumai.

Legelsőként vegyük szemügyre azt a hitelintézeti járadékot, amelyet 2007-ben vezettek be a magyar adórendszerbe. Tulajdonképpen egy lineáris, egy kulcsos adófajtáról van szó, amely a hitelintézeteknek az állami kamattámogatással vagy kamatkiegyenlítéssel közvetlenül, avagy közvetetten érintett hitelállománya után kerül felszámításra 5\%-os mértékkel. Tekintve, hogy ennél az adófajtánál az adó alapját nem a nyújtott szolgáltatások ára jelenti, az áthárítási effektus nem tud érvényesülni, vagyis elvileg a bankok nem tudják indirekt módon a fogyasztóval megfizettetni. De akkor mi is lehet a baj ezzel a hitelintézeti járadéknak csúfolt banki különadóval? A hitelintézetek egyik legnagyobb sérelme, hogy diszkriminatív, mégpedig azért, mert csupán azon az alapon sújtja magasabb adóteherrel a bankszektort, hogy az magasabb jövedelemmel rendelkezik a többi ágazathoz képest. Aggályos továbbá a szektorsemlegesség, intézménysemlegesség, jogbiztonság elvének a megtartása is. A legújabb fejlemények tükrében a 2016-os évben 6,3 milliárd forintos bevételt produkáló hitelintézeti járadék megszünik 2017-re, így a bankok adóterhelése ténylegesen csaknem 20 milliárd forinttal csökken az idei évet tekintve. Ez mindenféleképpen üdvözlendő hír, tekintettel arra, hogy mennyi diszfunkcióval küzdött az intézmény szabályozása. Viszont az már látható, hogy a hitelintézeti járadék eltörlése a hitelállományukon állami kamattámogatást élvező bankok számára lesz kedvező, ennek pontos mértékét ugyanakkor bankonként még nem ismerjük.

\section{Pénzügyi szervezetek különadója}

A legtöbb és legátfogóbb kritika eddig azonban nem a hitelintézeti járadékot érte hazánkban, hanem a pénzügyi szervezetek különadóját. Magas mértékére, kivetési 
módjára, felhasználására érkeztek panaszok. Felmerült a visszaható hatály problematikája is, mivel 2010-ben úgy került kivetésre, hogy a 2009-es mérlegföösszeg képezte az adószámítás alapját. A legnagyobb gond ugyanakkor az, hogy még 2016-ban is a bankadó alapját a hitelintézetek 2009-es korrigált mérlegföösszege adta. Nem kis iróniával mondhatom, hogy nem éppen volt naprakész, nem tudta követni a bankok jövedelemtermelö képességének a változásait. Gyakorlatilag azzal, hogy még mindig a 2009-es mérlegföösszeget vették alapul, nem voltak tekintettel arra, hogy ezeknek a bankoknak évröl évre csökkent a mérlegföösszege, kvázi egyre nagyobb érvágást jelentett számukra az adóteher viselése. 2017-re mind a bankadó alapja, mind pedig a kulcsa változott. A rendkívül elavult 2009-es mérlegföösszeg helyett új alapra került tehát a banki különadó, a két évvel korábbi mérlegföösszeget veszik figyelembe az adó alapjának számításakor. Január elsejét követően az ágazati adó felső kulcsa pedig 3 bázisponttal, 0,21 százalékra mérséklődött. Az elfogadott adótörvények szerint a bankadó 2017-ben és 2018-ban az adóalap 50 milliárd forintot meg nem haladó része után a 2016-ossal megegyezően 0,15 százalék. Egyelőre nem tisztázott, hogy ezzel melyik nagybanknak csillan meg a fény az alagút végén, csak annyit tudunk, hogy azoknak a bankoknak, amelyeknek a 2015-ös évben az átlagnál nagyobb mértékben nőtt a mérlegföösszegük, nem igazán fog kedvezni az új adószámítási módszer. A pénzügyi szervezetek különadóját, mint már említettem, átfogó kritika érte, amely nem merül ki a visszamenőleges hatály orvoslásának szükségességében. A versenysemlegesség elvének sérelmét azáltal valósítja meg a hazai szabályozás, hogy a nemzeti tulajdonban lévő takarékszövetkezeteknek kedvez és a többnyire részvénytársasági formában müködő hitelintézeteket pedig hátrányban részesíti. Az adózott eredményt tekintve tehát az Rt. formában müködő pénzintézeteket érte eddig a legnagyobb érvágás, tekintettel arra, hogy ezen intézmények magasabb mérlegföösszeggel rendelkeztek, magasabb adómérték volt rájuk irányadó, azaz az 50 milliárd feletti részre $0,53 \%$-os felső kulccsal kellett számolniuk. Várhegyi Éva tanulmányában így elemezte a helyzetet: ${ }^{3}$ a legkisebb fajlagos teher az OTP bankcsoportra hárult, amely a szektor 2009. évi adózás előtti eredményének kétharmadát „hozta össze”, miközben a mérlegföösszeg alapján elosztott különadónak csupán a negyede esett rá, az adó háromnegyede pedig a nyereség egyharmadával rendelkező bankokra jut. A különadó így 2010-ben tovább javította az OTP amúgy is kedvező relatív jövedelempozícióját, amelyet már a pénzügyi válság is elönyösen alakított.

$\mathrm{S}$ ha azt gondolnánk, hogy mindez a bírálat már épp eléggé megkérdőjelezi ennek a banki különadónak a jelenlegi formájában való létjogosultságát az adóztatási struktúrában, akkor nem állunk messze az igazságtól, de még nem számoltunk a kritika oldalán egy igen fontos érvvel. A pénzügyi szervezetek különadójából befolyó adóbevétel ugyanis 100\%-ban költségvetési bevételként jelenik meg. Az európai trendeket tekintve változó képet láthatunk, ugyanis hazánkkal egyetemben néhány országban szintén a központi költségvetés bevételét képezi a befolyt adó, de számos államban elkülönült alapba kerül, hogy az egy későbbi bankkrízis esetén mintegy tartalékalapként szolgáljon. Véleményem szerint ez utóbbi megoldást kellene preferálnia a magyar szabályozásnak is, hiszen egy speciális pénzügyi stabilizációs alap megléte esetén kevésbe kellene tartani attól, hogy egy, a bankszektort érintő válság

\footnotetext{
${ }^{3}$ http://econ.core.hu/file/download/vesz2011/bankszektor.pdf (letöltés dátuma: 2017. 03. 05.)
} 
során az államnak mentő csomagokkal kelljen beavatkoznia. De jelenleg az államkasszát gyarapítja a megfizetett banki különadó teljes összege. Ez ellen szóló érv lehet, hogy a hatás-ellenhatás mechanizmusában az extrém magas mértékü különadó visszavetheti a gazdasági növekedés mértékét és újból hiány keletkezhet a költségvetésben hosszú távon, mindezzel okafogyottá téve az adóztatás funkcióját.

1. táblázat

A banki különadókból származó bevételek alakulása a központi költségvetésben $(\mathrm{mrd} \mathrm{Ft})^{\text {ii }}$

\begin{tabular}{|c|c|c|c|}
\hline & $2016-$ os terv & $2017-e s$ terv & Változás, százalékban \\
\hline Hitelintézeti járadék & 6,3 & 0,0 & $-100,0 \%$ \\
\hline Pénzügyi szervezetek különadója & 79,2 & 66,5 & $-16,0 \%$ \\
\hline Pénzügyi tranzakciós illeték & 200,9 & 205,7 & $2,4 \%$ \\
\hline
\end{tabular}

Forrás: a táblázat a Portfolio.hu táblázatának felhasználásával készült. ${ }^{4}$

\section{Pénzügyi tranzakciós illeték}

Következzen a legfrissebb, de az átlagemberek számára leginkább ismert banki különadó fajta, a pénzügyi tranzakciós illeték. Kezdetben az MNB-re is ki akarták terjeszteni, de ez mind a jegybanktörvényt, mind pedig az uniós jogot sértette volna, így még 2012-ben sor került a törvényjavaslat módosítására, melynek eredményeként 2013ban már e rendelkezés nélkül léphetett hatályba. A tranzakciós illeték a lakossági, vállalati banki, illetve postai tranzakciókra irányadó, adóalapja meglehetősen széles, mértéke pedig az adó alapjául szolgáló tranzakció értékének 0,1\%-a. Természetesen a pénzügyi tranzakciós illeték igen negatív fogadtatásra talált nemcsak a bankszektor szereplöinek körében, hanem a fogyasztók is ennek a banki különadónak a hátrányaival szembesültek a legközvetlenebb módon. Az áthárítási effektus, vagyis az adóteher viselésének a fogyasztókra történő telepítése egyértelműen megállapítható volt. Az MNB 2014-es elemzése alapján a 11 legnagyobb hitelintézet több lépésben hárította át az ügyfeleire a tranzakciós illetéket, mind a bevezetésekor, mind pedig a kulcsok megemelésekor. Az ezzel szembeni éles társadalmi ellenállás kompenzálására próbált reagálni a jogalkotó azzal, hogy kötelezte a pénzintézeteket arra, hogy havi kétszeri, összesen legfeljebb 150.000 Ft-ig terjedő készpénzfelvételt biztosítsanak ügyfeleiknek. A tranzakciós illeték jelentősége azonban nem vitatható, megjelenésének évében több mint 20\%-kal csökkentette a hiányt. A Budapest Bank 2015-ben készült felméréséböl ${ }^{5}$ az derült ki, hogy a hazai lakosság többsége havonta egyszer vagy kétszer vesz fel ATM-böl készpénzt. A bankkártyás fizetések gyakorisága ennél jóval magasabb lett, illetve tíz alkalomnál is többször fizetnek bankkártyával a vásárlások során. A havi kétszeri ingyenes készpénzfelvétel lehetőségét a hazai lakosság túlnyomó többsége igényelte, de továbbra is alacsony a bankváltások száma a hazai lakosság körében, az ügyfelek háromnegyede az elmúlt 10 évben még egyszer sem váltott pénzintézetet. A nagybankokra gyakorolt hatását tekintve megállapíthatjuk, hogy a tranzakciós illeték hatására sem volt opció számukra a kivonulás, inkább a költségek redukálására törekedtek. Ez tulajdonképpen bankfiókok bezárását, dolgozók

\footnotetext{
${ }^{4}$ http://www.portfolio.hu/gazdasag/adozas/itt_vannak_a_2017es_koltsegvetes_legnagyobb_erdekessegei.230982.html (2017.02.20)

${ }^{5}$ https://www.budapestbank.hu/info/sajtoszoba/images/attach/20150109104148_att_867.pdf
} 
létszámának leépítését eredményezte. Ezzel párhuzamosan megfigyelhető volt természetesen a szolgáltatási díjak emelése, az infláció gerjesztése, ami magával vonzotta a fogyasztás csökkenését. A tranzakciós illeték eredményeként több mint 300 ezerrel csökkent a bankszámlák száma Magyarországon.

A leírtakat összegezve megállapíthatjuk, hogy önmagában a különadók léte, rendszerük fenntarthatósága, hatékony müködtetése nem teljesen lehetetlen próbálkozás. Ugyanakkor, különös tekintettel a banki különadókra, látnunk kell, hogy mennyi diszfunkcióval küzd a hazai szabályozásuk. Ahogy a mondás tartja, bevezetésükkel "amennyit nyertünk a réven, annyit veszítettünk a vámon." A banki különadók átgondolatlan, kiforratlan, rövid idő alatt történő bevezetése a bankrendszer eredményességének lényeges romlásához, a nem teljesítő hitelek számának növekedéséhez, a hitelezési képesség visszaeséséhez, hitelkínálat szükítéséhez vezetett. Nemzetközi viszonylatban pedig az instabil piaci környezet mindenféleképpen demotiválóan hatott a befektetési és beruházási kedvre, hiszen a bizonytalan adórendszer riasztóan hat a külföldi befektetőkre, így a gazdasági növekedés potenciálját, ha nem is parkoló pályára tette, de mindenféleképpen lassította annak ütemét. Úgy gondolom, hogy ezeknek a különadóknak az átgondolásával, újraszabályozásával, a meglévő adóterhek mértékének csökkentésével lehetőség nyílhatna arra, hogy levetkőzhessék válságadó jellegüket. Mindenesetre üdvözlöm a kormány 2017-es költségvetési tervezetében a banki különadókra vonatkozó rendelkezéseit, s bízom abban, hogy az új szlogen úgy hangzik majd, hogy:... a bankszektort élni és élni hagyni!

\section{Források:}

Várhegyi Éva: A magyar bankszektor szabályozása és versenyhelyzete a válságban. Verseny és $\quad$ szabályozás, 2011, 5. évf. 1 . sz.http://econ.core.hu/file/download/vesz2011/bankszektor.pdf (2016.11.01) https://www.asz.hu/storage/files/files/penzugyiszemle/2012/355_367_kovacs.pdf (2016. 11.01)

https://www.budapestbank.hu/info/sajtoszoba/images/attach/20150109104148_att_867. pdf (2016.11.01)

Siklós Márta - Mladonyiczki Balázs: Különadók szerepe az adózásban. http://adozasrolerthetoen.blog.hu/2016/03/16/siklos_marta_mladonyiczki_b alazs kulonadok_szerepe az_adozasban (2016.11.01)

http://m.portfolio.hu/finanszirozas/bankok/megvan_hogy_csokkenti_a_kormany_a_ban kadot.231311.html (2016.11.15)

http://www.portfolio.hu/finanszirozas/bankok/eltorli_a_kormany_a_magyar_bankok_eg yik_adojat.230940.html (2016.11.15)

http://www.piacesprofit.hu/kkv_cegblog/20-milliarddal-kevesebbet-ker-a-bankoktol-akormany/(2016.11.15)

http://hvg.hu/gazdasag/20160316_kulonadok_leitnerleitner_adiztatas_allami_bevetelek (2016.11.01)

http://profitline.hu/hircentrum/hir/361013/Tovabb-csokken-a-bankado-2017-

ben $(2017.02 .20)$ 